\title{
Charakterystyczne rysy teologii moralnej Bernharda Häringa
}

Bernhard Häring (1912-1998), niemiecki redemptorysta, należy do najwybitniejszych teologów moralistów minionego stulecia. Zarówno jego duszpasterskie zaangażowanie, jak i naukowa praca służyły odnowie teologii moralnej, która od kilku stuleci charakteryzowała się ujęciem jurydycznym. Dla odnowy tej dyscypliny Häring posłużył się antropologią, filozofią (tu zwłaszcza personalizm, egzystencjalizm, fenomenologia), Pismem Świętym, teologią (m.in. duchowość, dogmatyka, liturgika), naukami szczegółowymi (m.in. medycyna, psychologia, psychoterapia).

Ponieważ charakterystyczne rysy jego teologii moralnej stanowią temat bardzo szeroki i obszerny, dlatego zostaną one jedynie wymienione i bardzo krótko omówione. Pozytywną stroną takiej metodologii jest ukazanie ogromu pracy tego moralisty, czego dowodem są podręczniki do teologii moralnej, liczne książki i niezliczone artykuły, a także wciąż rosnąca liczba różnych opracowań myśli Häringa. Pokazują one i potwierdzają fakt, że wachlarz jego zainteresowań na polu teologii moralnej 
był bardzo szeroki. Ponadto ukazanie tak wielu charakterystycznych rysów jego teologii moralnej pozwala na pełniejsze rozumienie całej jego myśli moralnej.

Na obrany temat składają się cztery punkty:

1) Kierunki odnowy teologii moralnej.

2) Wiodące tematy teologii moralnej.

3) Przyczyny różnic z oficjalną nauką Kościoła.

4) Znaczenie myśli teologicznomoralnej Häringa.

Chociaż punkt trzeci i czwarty są bardzo krótkie w stosunku do pierwszego i drugiego oraz dość nietypowe, to jednak wydają się stanowić istotne dopełnienie charakterystycznych rysów jego teologii moralnej.

\section{Kierunki odnowy teologii moralnej}

Charakterystyczną cechą teologii moralnej Häringa jest bardzo świadome i konsekwentne dążenie do jej odnowy. Obejmuje ona wiele płaszczyzn. By zrozumieć jej całokształt, należy te płaszczyzny wymienić i krótko omówić.

\subsection{Od legalizmu i kazuistyki do chrześcijańskiego personalizmu}

Dotychczasowa teologia moralna, ugruntowana na pryncypiach prawa naturalnego i kanonicznych normach, była za mało teologią. Häring konsekwentnie dążył do zmiany paradygmatu: od etyki posłuszeństwa dla poddanych w Kościele do etyki odpowiedzialności dla dojrzałych chrześcijan. W teologii moralnej wskazał na wzniosłość chrześcijańskiego powołania i własną 
odpowiedzialność, co sugeruje konstytucja duszpasterska Soboru Watykańskiego II w miejscach odnoszących się do zagadnień sumienia ${ }^{1}$. Zdaniem Häringa, teologia moralna winna ukazywać ludziom horyzonty nauki katolickiej wolne od legalizmu i kazuistyki ${ }^{2}$, natomiast działanie moralne winno sięgać o wiele głębszych pokładów duszy niż tylko zachowywanie uwarunkowanych historycznie norm prawnych.

Häring stawia sobie również za cel przejście od legalistycznej teologii moralnej podręczników do biblijnego i pastoralnego ujęcia zagadnień moralnych, zgodnie ze wskazaniami Soboru Watykańskiego II. Stąd Nauka Chrystusa była jedynie przejściowym etapem w całej myśli Häringa ${ }^{3}$. Odrzucił on również legalistyczny status sakramentów, jaki miały w podręcznikach do teologii moralnej od czasów trydenckich. Zobowiązania odnośnie do administrowania i przyjmowania sakramentów umieszczano w nich w trzeciej i ostatniej części. Zamiast określać cześć należną Bogu i sakramenty jako moralne zobowiązania, które łączą chrześcijan, Häring usytuował te dwa elementy w centrum chrześcijańskiego życia oraz dokonał redefinicji ich pojęć w kontekście swojej teologii odpowiedzi i dialogu. Angażując się w prace ruchu

Por. J. Gründel, Bernhard Häring. Wegbereiter einer lebensnahen Moraltheologie, w: Theologen unserer Ziet. Mit Beiträgen von Karl Lehmann, Hanna-Barbara Gerl-Falkovitz, Elmar Salmann, Norbert Göttler, Richard Heinzmann, Gerd Haeffner, Johannes Gründel, Friedhelm Hengsbach, Rudolf Hoppe, Arno Schilson, Gerhard Ludwig Müller, red. S. Pauly, StuttgartBerlin 1997, s. 105-106.

2 Por. A. Marcol, Profesor Bernhard Häring - teolog moralista. Wstępna analiza, „Studia Theologica Varsaviensia” 29 (1991), nr 2, s. 119; S. Olejnik, Dar - Wezwanie - Odpowiedź, t. 1, Warszawa 1988, s. 109-110.

3 Por. K.A. Cahalan, Formed in the Image of Christ. The Sacramental-Moral Theology of Bernhard Häring, C.Ss.R., Collegeville, Minnesota 2004, s. $24-25$. 
liturgicznego, szukał miejsca czci we właściwej relacji do życia moralnego i duchowego wzrostu ${ }^{4}$.

Zwrot od legalizmu do chrześcijańskiego personalizmu zauważa się $\mathrm{w}$ dążeniu do zmiany paradygmatu: od etyki posłuszeństwa prawu do etyki odpowiedzialności oraz od moralnego indywidualizmu do chrześcijańskiej solidarności w zbawieniu ${ }^{5}$. Wymóg posłuszeństwa prawu stawiany przez Kościół wiernym Häring zastępował budzeniem świadomości wobec wartości. Teologia moralna winna być głoszeniem Dobrej Nowiny, która uszczęśliwia człowieka i daje mu poczucie spełnionego życia. Redemptorysta zdawał sobie sprawę z niebezpieczeństwa powstania przepaści między postawą wymagającego posłuszeństwa moralisty a wolnością sumienia jednostki. Doceniając wartość nauczania Kościoła, jednocześnie podkreślał, że trzeba uznać godność człowieka i tę zbyt mało wyeksponowaną prawdę, iż każdy ochrzczony jest prowadzony przez Ducha Świętego ${ }^{6}$. Stąd też struktura moralności w ujęciu Häringa ma wyraźnie przesunięty punkt ciężkości z posłuszeństwa normom zewnętrznym na osobistą odpowiedzialność pojedynczego wierzącego. Nie może to jednak oznaczać relatywizacji obiektywnego prawa moralnego ani przypisania rangi absolutnej normy zwykłemu i powierzchownemu osądowi pojedynczego sumienia. Häring rozwija tutaj soborowy impuls, który podkreślił godność sumienia i zwrócił uwagę na doniosłość osobistej odpowiedzialności ${ }^{7}$.

Por. tamże, s. 29.

Por. J. Gründel, Bernhard Häring, dz. cyt., s. 109.

Por. A. Marcol, Profesor Bernhard Häring..., dz. cyt., s. 121.

Por. M. Machinek, Znaczenie myśli Bernharda Häringa w posoborowym dziele odnowy teologii moralnej, w: Wybitni teologowie XX wieku. Krąg języka niemieckiego, red. J. Jezierski, K. Parzych, Olsztyn 2006, s. 117-118. 


\subsection{Orientacja biblijna}

Oddzielając teologię moralną od prawa kanonicznego, Häring złączył ją z Nowym Testamentem i całym Pismem Świętym, zgodnie z myślą Soboru Watykańskiego II, zawartą w dekrecie o formacji kapłańskiej Optatam totius, w numerze $16^{8}$. Od samego początku zauważa się u Häringa świadome i konsekwentne otwarcie teologii moralnej na Pismo Święte, a ów akapit w soborowym dekrecie, który zaleca teologii moralnej, by bardziej żywiła się Biblią, pochodzi od niego. Nie ulega wątpliwości, że do tego otwarcia się na Pismo Święte przyczynili się wielcy odnowiciele teologii moralnej związani zwłaszcza $z$ uniwersytetem w Tybindze ${ }^{9}$, gdzie Häring kończył doktorat. Byli to m.in.: J.M. Sailer (1751-1832), J.B. Hirscher (1788-1865), F.X. Linsenmann (1835-1898), F. Tillmann (1874-1953) i Th. Steinbüchel (1888-1949). Ten ostatni był promotorem jego pracy doktorskiej. Wpływ na biblijny zwrot w teologii moralnej Häringa miał również Magnus Jocham (1808-1893), zaliczany do odnowicieli teologii moralnej na fundamencie biblijnym.

Häring analizuje biblijne tematy, paradygmaty i obrazy izraelskiego i chrześcijańskiego doświadczenia i w oparciu o nie buduje portret chrześcijańskiego życia moralnego ${ }^{10}$. Ponadto utożsamia

8 Por. Sobór Watykański II, Dekret o formacji kapłańskiej Optatam totius (28 października 1965), w: Sobór Watykański II, Konstytucje, dekrety, deklaracje, Poznań 2002, nr 16, s. 286-300.

9 Dla porównania teologii moralnej wykładanej w seminarium Häring już wtedy zaczął dogłębnie studiować m.in. pisma J.M. Sailera, J.B. Hirschera i F. Tillmanna. Było to jego pierwsze, lecz nie ostatnie spotkanie $\mathrm{z}$ tymi moralistami. Będzie się do nich odnosił w całej swojej pracy naukowej. Por. B. Häring, Geborgen und frei. Mein Leben, Freiburg-Basel-Wien 1997, s. 22, 104.

10 Por. K.A. Cahalan, Formed in the Image of Christ, dz. cyt., s. 13. 
normy i pryncypia Dekalogu z tymi, które zawarte są w Kazaniu na górze, uważając je za drogowskazy dla człowieka w jego odpowiedzi na Boże wezwanie ${ }^{11}$. W Piśmie Świętym Häring znajduje centralną dla teologii moralnej myśl, która wyraża się w dynamice pomiędzy łaskawą i w sposób wolny ofiarowaną człowiekowi inicjatywą oraz zaproszeniem od Boga a indywidualną i wspólnotową odpowiedzią Mu, wyrażającą się w czci i moralnych relacjach. W ten sposób tworzy się dynamika i dialog, które podkreślają zarówno przymierze Starego Testamentu, jak i bycie uczniem w Nowym. Aby pojąć tę dynamikę, używa on pojęć odpowiedzialności i wolności. Odpowiedzialność łączy religię i moralność. Religia wyraża się w adoracji i czci, które są odpowiedzią wspólnoty na łaskawy Boży dar stworzenia i życia. Moralność natomiast składa się z wolnej i wiernej odpowiedzi Bogu (przez wierne posłuszeństwo) oraz bliźniemu (przez miłość i służbę) ${ }^{12}$.

Zwrot do tematów biblijnych stanowi pierwsze $\mathrm{z}$ wielu odejść Häringa od tradycji podręczników. Opierając się na Piśmie Świętym, zapoczątkował on istotną zmianę w metodzie i treści katolickiej teologii moralnej. W Nowym Testamencie odnalazł fundament dla moralności, która jest otwarta, dynamiczna, pozytywna i osobowa. Nadto Biblia stanowi dla niego teologiczną bazę do przezwyciężenia zamkniętej, statycznej, negatywnej i nieosobowej teologii moralnej, która panuje w podręcznikach ${ }^{13}$.

Biblijne zorientowanie teologii moralnej Häringa zaowocowało chrystocentryzmem i związaną z nim tzw. etyką naśladowania Chrystusa. Jego chrystocentryzm w teologii moralnej najpełniej oddają następujące słowa: „Chrystus jest normą, centrum

11 Por. tamże.

12 Por. tamże, s. 14.

13 Por. tamże, s. 15. 
i celem teologii moralnej. Prawem chrześcijanina jest nic innego, jak właśnie sam Chrystus" ${ }^{14}$. Jego teologia moralna nie jest ani etyką cnót, ani etyką obowiązków, ani nauką o normach, ani etyką konkretnych rozstrzygnięć, ani moralnością przykazań, ani nauką o sumieniu, lecz etyką naśladowania Chrystusa ${ }^{15}$. M. Clark zauważa, że jest ona głównie chrystologiczna, ponieważ człowiek został stworzony na obraz Boży, a Chrystus jest doskonałym obrazem Bożym ${ }^{16}$ oraz wcieleniem miłości Ojca ${ }^{17}$.

\subsection{Chrześcijański personalizm}

W punkcie 1.1. został już krótko zasygnalizowany chrześcijański personalizm. W tym miejscu warto mu się nieco bliżej przyjrzeć, by lepiej zrozumieć jego rolę w teologii moralnej. Häring, odwołując się do personalizmu i Schelerowskiej filozofii wartości, tworzy jednocześnie swój własny personalizm ${ }^{18}$, za po-

14 B. Häring, Nauka Chrystusa. Teologia moralna, t. I: Zasadnicza postać chrześcijańskiego życia. Teologia moralna ogólna, tłum. J. Klenowski, Poznań 1962, s. 9. Por. M. Machinek, Znaczenie myśli Bernharda Häringa..., dz. cyt., s. 112-113. Por. K.A. Cahalan, Formed in the Image of Christ, dz. cyt., s. 13.

15 Por. E. Schockenhoff, Pater Bernhard Häring als Wegbereiter einer konziliaren Moraltheologie. 50. Jahre: „Das Gesetz Christi”, w: 50 Jahre „Das Gesetz Christi”. Der Beitrag Bernhard Härings zur Erneuerung der Moraltheologie. Mit Beiträgen von K. Arntz, R. Gallagher, B. Hidber, J. Römelt, E. Schockenhoff und M. Vidal (Studien der Moraltheologie, Abteilung Beihefte, 14), Münster 2005, s. 47.

16 Por. M. Clark, The major scriptural themes in the moral theology of father Bernhard Häring, cz. I, „Studia Moralia” 1992, nr 1, s. 4, przyp. 6.

17 Por. A. Marcol, Profesor Bernhard Häring..., dz. cyt., s. 120-121.

18 K. Cahalan zauważa w teorii wartości i personalizmie, które Häring wykorzystuje w swoich pracach, brak filozoficznej integracji i spoistości. Przez tak silne uwydatnienie doświadczenia w religijnych i moralnych terminach Häring nie uwzględnia zarówno metafizycznych, jak i filo- 
mocą którego wyraża m.in. relację między religią i moralnością, rozumienie osoby, przeżycia moralnego, doświadczenia moralnego, wspólnoty osób itd. W dotychczasowej teologii moralnej zauważa on bezduszny jurydyzm, który nie zostawia miejsca na spotkanie człowieka $\mathrm{z}$ Bogiem. W związku z tym proponuje ujmowanie moralności w modelu wezwanie-odpowiedź. W tym dialogicznym ujęciu moralności Bóg wzywa człowieka do siebie, a człowiek odpowiada na Jego wezwanie postawą nieustannego nawracania się. Dialogiczny model łączy w sobie wezwanie Boga i odpowiedź człowieka ${ }^{19}$. Bóg wzywa człowieka do życia w miłości i jedności z sobą, człowiek natomiast swoim życiem odpowiada na Boże wezwanie. Szczególną rolę w tej odpowiedzi odgrywa sumienie, w którym uwydatnia się to, jak bardzo charakterystyczne, jedyne i niepowtarzalne jest samorozumienie się człowieka w świetle wezwania Boga. Bóg zobowiązuje człowieka w jego sumieniu, w sercu, w centrum jego istnienia. Wierzący odczuwa w sobie, że Boże wezwanie przynosi życie dzięki jego afirmacji lub śmierć, rozdarcie serca w przypadku odmowy ${ }^{20}$. Dla tych, którzy osiągnęli pełną świadomość wiary, wezwanie Boga jest momentem decyzji, sposobnością osobistej odpowiedzi $\mathrm{Mu}$, czasem owocowania, łaski i wzrostu ${ }^{21}$. Człowiek staje się odbi-

zoficznych wymogów, pomimo że odnoszą się one do dziedziny moralnej. W rzeczywistości zmierza do odrzucenia wszystkich filozoficznych spekulacji, pierwotnie odnoszonych się do metafizycznych kategorii bytu jako bytu. Por. K.A. Cahalan, Formed in the Image of Christ, dz. cyt., s. 24-25.

19 Por. V. Schurr, Bernhard Häring. Die Erneuerung der Moraltheologie, Salzburg 1970, s. 37-64.

20 Por. B. Häring, Christ in einer neuen Welt. Lebensgestaltung aus dem Glauben, Bonn 1958, s. 105.

21 Por. tenże, Moralność jest dla ludzi. Etyka chrześcijańskiego personalizmu, tłum. H. Bednarek, Warszawa 1975, s. 180. 
ciem Boga wówczas, kiedy dostrzega Go i Jego miłość oraz przyjmuje postawę podziwu i uwielbienia ${ }^{22}$. Jest to najdoskonalsza forma odpowiedzi danej Bogu przez człowieka, którą Häring włącza w podstawową strukturę swojej antropologii. Bez odpowiedzi Bogu nie jest się w pełni człowiekiem. Do prawdziwej tożsamości i autentyczności człowiek dochodzi w akcie przyjęcia wezwania w jego całości, to jest w przyjęciu wezwania Miłości do miłości, do dialogu, do słuchania i odpowiedzi ${ }^{23}$.

Bóg, który jest Miłością, oczekuje takiej samej odpowiedzi ze strony człowieka. Wzór doskonałej odpowiedzi człowiek znajduje w Jezusie Chrystusie, który zaprasza go do odnowy życia przez odpowiedź miłością na Miłośćc ${ }^{4}$. Doskonała odpowiedź składana Bogu w Jezusie Chrystusie ma miejsce w Eucharystii, która jest wstępowaniem człowieka we wszystko ogarniającą miłość Jezusa oraz składaniem miłego Bogu dziękczynienia i uwielbienia ${ }^{25}$. Odpowiedź dawana Bogu w Jezusie Chrystusie polega na naśladowaniu Go i dokonuje się w egzystencjalnej wierze, przez którą człowiek w zaufaniu powierza się Bogu. Wiara w miłości jest żywa, przynosi owoc, ożywia się w sakramentach i znakach zbawienia oraz chce odcisnąć swoje piętno na zasadniczej postawie człowieka $^{26}$. To ona musi stać się sercem wszystkiego i obejmować swoim zasięgiem sferę wewnętrzną i zewnętrzną człowieka,

22 Por. tenże, Herz Jesu und das Heil der Welt, St. Ottilien 1983, s. 20.

23 Por. tenże, Paternità responsabile, Roma $1973^{2}$, s. 9.

24 Por. tenże, Erziehung zur Christusliebe im Beichtstuhl, „Anima” 12 (1957), s. $262-267$.

25 Por. tenże, Frei in Christus. Moraltheologie für die Praxis des christlichen Lebens. Das Fundament aus Schrift und Tradition, t. I, Freiburg-BaselWien 1979, s. 38.

26 Por. tenże, Vom Glauben, der gesund macht. Ermutigung der heilenden Berufe, Freiburg-Basel-Wien 1984, s. 63. 
jak i międzyludzkie relacje oraz pierwotny stosunek do rzeczy ${ }^{27}$. Kochający Ojciec chce w Jezusie prawdziwego dialogu, który zdecydowanie różni się od wyuczonych na pamięć sformułowann ${ }^{28}$.

Häring w swoim personalizmie poświęca wiele uwagi osobie ludzkiej. Ujmuje ją jako byt dynamiczny, wyposażony we własną wolność, kształtowany jednak przez kulturę i warunkowany przez historię ${ }^{29}$. Osoba jest dlań nie tylko indywidualnością, lecz także tworzy społeczności i potrzebuje wspólnoty do pełnego rozwoju swojego potencjału. Tworzenie wspólnot wynika $z$ dynamicznego charakteru relacyjności osoby. Jako byt relacyjny w czasie i historii, osoba jest podmiotem wartości oraz podejmuje wysiłek maksymalizacji wartości w stworzonym porządku. W ten sposób Häring wypracował antropologię teologiczną znacznie różniącą się od metafizycznych kategorii neotomistycznych ${ }^{30}$.

Położenie akcentu na postawę człowieka wobec wartości nie tylko stanowi cenne ubogacenie podmiotowego wymiaru moralnego działania, lecz przede wszystkim ukazuje rolę miłości w moralnym działaniu oraz bogactwo wewnętrznego przeżycia osoby. Häring włączył przy tym emocjonalną sferą osoby do moralnego działania i ukazał, że za jej pomocą rodzi się coraz głębsza zażyłość podmiotu z przedmiotem, czyli wartością, do której on podąża. Więź podmiotu z przedmiotem-wartością urzeczywistnia się w głębi istoty człowieka.

Personalistyczny charakter teologii moralnej Häringa przejawia się w jego trosce o religijną dojrzałość każdego człowieka, co

27 Por. tenże, Personalismus in Philosophie und Theologie, München-Freiburg i. Br. 1968, s. 40-41.

28 Por. tenże, Frei in Christus. Moraltheologie für die Praxis..., t. I, dz. cyt., s. 84.

29 Por. K.A. Cahalan, Formed in the Image of Christ, dz. cyt., s. 17-18.

30 Por. tamże, s. 16. 
wyraża się w akcencie położonym nie tylko na twórczą odpowiedzialność, lecz także na kreatywną wolność, wierność oraz sumienie, które prowadzą człowieka do dojrzałości ludzkiej i religijnej. Tak rozumiana moralność jest daleka od zakazu, prawa, powinności. Docenia ona podmiot moralny w relacji do Boga i bliźnich. Jest nim człowiek dojrzały, dojrzale podchodzący do wiary, odpowiedzialny za siebie oraz współodpowiedzialny za środowisko i innych ludzi. Fundamentem tej odpowiedzialności jest spotkanie z osobowym Bogiem-Miłością oraz uczestnictwo we wspólnocie $z$ innymi ludźmi. Häring uzasadnia ideę odpowiedzialności w oparciu o koncepcję powołania chrześcijanina przez Chrystusa w całej pełni jego osobowości, to jest jako istoty społecznej, historycznej, modlącej się i włączonej w kult. Akcentuje jednocześnie wolność, która wraz z odpowiedzialnością stają się naczelnymi ideami. W takim ujęciu o specyfice życia chrześcijańskiego stanowią twórcze działanie chrześcijanina powołanego w wolności i jego wierna odpowiedźz ${ }^{31}$. Idea odpowiedzialności staje się więc dla Häringa fundamentalną kategorią nauki moralnej, istotną zdolnością osoby ludzkiej i podstawą działania moralnego. Tak ujęta leży u podstaw nowego rozumienia norm moralnych. Odnosi się zarówno do konkretnych przykazań (Erfüllungsgebote), jak i przykazań prowadzących do celu (Zielgobote). Te ostatnie należy rozumieć nie jako utopię lub niemożliwe do spełnienia i nieobowiązujące ideały, lecz jako wskazania, które nadają wszystkim konkretnym przykazaniom dynamizm, sens i cel ${ }^{32}$.

31 Por. J. Pryszmont, Z historii teologii moralnej w ostatnich wiekach. W kierunku odnowy, „Studia Theologica Varsoviensia” 21 (1983), nr 1, s. 48-49.

32 Por. B. Häring, Frei in Christus. Moraltheologie für die Praxis..., t. I, dz. cyt., s. 98; M. Machinek, Znaczenie myśli Bernharda Häringa..., dz. cyt., s. 117. 
Häring opowiada się za całkowitym szacunkiem dla wolności i osądu sumienia pojedynczego człowieka. Taka postawa jest konsekwencją miłości objawionej w Chrystusie oraz miary miłości, która znaczy więcej niż prawo ${ }^{33}$. Szczególnie akcentuje jednak dojrzałość sumienia osoby. Nie polega ona na wyzwoleniu się od Ewangelii i głoszonych przez Kościół ogólnych norm, z uwzględnieniem jednorazowej sytuacji i sumienia jednostki, lecz na umiejętności samodzielnego stosowania owych norm w konkretnej sytuacji oraz dostrzegania i wypełniania chrześcijańskich obowiązków i zadań w świetle kairosu. Häring zdaje sobie sprawę z niebezpieczeństwa, jakie wiąże się z osądem sumienia jednostki, dlatego poddaje pojedynczą decyzję obiektywnej weryfikacji w spotkaniu i wymianie doświadczeń z innymi. Samą zaś moralność wkłada w ramy sprawiedliwości, umiarkowania i miłości. Dojrzałość sumienia osoby urzeczywistnia się dzięki wolności, która żyje z wiary i zjednoczenia z Jezusem Chrystusem. Za sprawą wolności człowiek staje się dojrzały, cieszy się życiem i postępuje według dobrze uformowanego sumienia we wspólnocie Kościoła ${ }^{34}$. Wolność według Häringa należy pojmować w znaczeniu biblijnym i głęboko teologicznym, jako możność odpowiedzialnego wyboru dobra i opowiedzenia się za realizacją miłości, której przypisuje w swej wizji moralności wyjątkową rolę ${ }^{35}$.

33 Por. W. Nethöfel, Moraltheologie nach dem Konzil. Personen, Programme, Positionen (Kirche und Konfession, 26), Göttingen 1987, rozdz. 1: Vom Gezetz Christi zur Freiheit in Christus Bernhard Häring, s. 63.

34 Por. J. Gründel, Bernhard Häring..., dz. cyt., s. 102.

35 Por. F. Greniuk, Katolicka teologia moralna $w$ poszukiwaniu własnej tożsamości, Lublin 1993, s. 43. 
Centralna teza filozofii Schelera głosi, że religia i moralność są od siebie nawzajem istotnie zależne na ich najwyższym, doskonałym stopniu. Häring podejmuje ją, rozwija i czyni z niej podstawę odnowy teologii moralnej, którą określa się mianem „ontologicznego personalizmu”. Teza ta zarazem stanowi punkt wyjścia w ontologiczno-osobowym spojrzeniu na dziedzinę zagadnień teologicznomoralnych ${ }^{36}$. Połączenie religii i moralności spotkamy już w rozprawie doktorskiej Häringa. Chociaż fenomenologicznie rzecz ujmując, religia i moralność stanowią dwie różne rzeczywistości, spotykają się ze sobą w odpowiedzialności. Pojęcie „odpowiedzialności” staje się kluczowe, ponieważ odzwierciedla dialogiczną strukturę religii z jednej strony oraz moralności i mocniejszej religijnej moralności z drugiej. Religijność w Das Gesetz Christi znajduje wyraz jako żywotna dialogiczna rzeczywistość, która opiera się na spotkaniu człowieka z Bogiem. W wyniku spotkania z Bogiem człowiek doświadcza najgłębszej prawdy o sobie samym i może osiągnąć pełnię swojej osobowości. Tak więc już pierwsze dzieło Häringa przedstawia koherentny (spójny) opis religijnej moralności. Sam autor zauważał, że podręczniki z jego czasu nie były jej wyrazem ${ }^{37}$.

Przez połączenie religii i moralności Häring pokonał długo trwający rozdział pomiędzy teologią moralną a duchowością. Te dyscypliny były oddzielone od czasów Soboru Trydenckiego ze względu na ich cel. Teologia moralna określała minimalne wymagania chrześcijańskiego życia, aby zapewnić wiernym zbawienie, a teologia duchowości określała wymagania dla duchownych,

36 Por. W. Nethöfel, Moraltheologie nach dem Konzil..., dz. cyt., s. 31-32.

37 Por. R. Gallagher, „Das Gesetz Christi” - Seine Bedeutung für die Erneuerung der Moraltheologie, w: 50 Jahre „Das Gesetz Christi”, dz. cyt., s. 11-42. 
jakie powinni spełnić, by dojść do doskonałości poprzez modlitwę, kontemplację i zjednoczenie mistyczne. Häring twierdził, że życie doskonałe, świętość i wzrost w Bożej łasce stanowią wezwanie skierowane do wszystkich chrześcijan, a nie tylko do duchownych. Życie moralne związane jest z życiem modlitwy, kontemplacją oraz $\mathrm{z}$ wewnętrznymi i zewnętrznymi czynami cnoty religijności. Zintegrował on tym samym teologię sakramentalną i teologię duchowości z teologią moralną. To podejście kontynuował przez cały okres twórczości naukowej ${ }^{38}$.

Ponadto Häring adaptuje i rozwija także inną myśl Schelera. Odnosi się ona do tego, że pojedyncza osoba i wspólnota jako osoba są podmiotami moralnej wartości zwłaszcza wtedy, gdy mówi o odpowiedzialności pojedynczej osoby i wszystkich w Kościele oraz o naśladowaniu Chrystusa ${ }^{39}$. Teoria wartości pozwoliła mu umieścić normy i przykazania w szerszym kontekście egzystencjalnym. Osoby stają się świadome wartości poprzez samowiedzę i relacje $z$ innymi. W ten sposób mogą poznać i wybrać dobro na podstawie własnych doświadczeń wartości, a nie z racji wiedzy o abstrakcyjnych normach i przykazaniach ${ }^{40}$.

\subsection{Orientacja egzystencjalna i pastoralna}

J. Gründel zalicza Häringa do prekursorów bliskiej życiu teologii moralnej ${ }^{41}$. Powiązanie jej z życiem wynika z nieustannego i twórczego kontaktu Häringa z człowiekiem. Egzystencjalny

38 Por. K.A. Cahalan, Formed in the Image of Christ, dz. cyt., s. 28-29.

39 Por. tamże, s. 33.

40 Por. tamże, s. $15 \mathrm{n}$.

41 Por. J. Gründel, Bernhard Häring..., dz. cyt., s. 98. 
charakter jego teologii moralnej zauważa się w całościowym ujęciu osoby ludzkiej, ukazywanej w kontekście otaczającego ją środowiska, zarówno społeczeństwa, w którym żyje, jak i wspólnoty eklezjalnej, której jest członkiem, a także w jej historyczności i kairosie ${ }^{42}$. W. Nethöfel pisze, że teologia moralna Häringa jest teologią bliską życiu, ponieważ czerpie z doświadczeń życiowych $^{43}$.

Obok ukierunkowania na życie konkretnego człowieka teologia moralna Häringa charakteryzuje się także pastoralną orientacją. Jako wierny naśladowca św. Alfonsa, żył on problemami ludzi i uprawiał teologię dla duszpasterstwa ${ }^{44}$. K. Cahalan zauważa ścisły związek pomiędzy pastoralnym ukierunkowaniem teologii moralnej Häringa a jego przynależnością do Zgromadzenia Redemptorystów, które założył wrażliwy na potrzeby opuszczonych św. Alfons Liguori. Jego zdaniem, Häring w swoich pracach wcielił wiele tematów typowych dla św. Alfonsa, jak: bliska obecność Bożej miłości i miłosiernej łaski, wezwanie wszystkich ochrzczonych do świętości, prymat prawa serca i drugorzędna rola kościelnych norm i praw w moralności, wolność sumienia wierzącego i jego formacja w Kościele oraz idea spowiednika bardziej jako duchowego i moralnego przewodnika niż sędziego ${ }^{45}$. Duszpasterska praca stanowiła więc fundament teologii Häringa ${ }^{46}$. Zaproponowane przezeń pastoralne

42 Por. J. Pryszmont, $Z$ historii teologii moralnej..., dz. cyt., s. 47-48; tenże, Historia teologii moralnej, Warszawa 1987, s. 195.

43 Por. W. Nethöfel, Moraltheologie nach dem Konzil..., dz. cyt., s. 25.

44 Por. A. Marcol, Profesor Bernhard Häring..., dz. cyt., s. 120.

45 Por. K.A. Cahalan, Formed in the Image of Christ, dz. cyt., s. 18.

46 Por. tamże, s. 19. 
zbliżenie przypomina moralistom o potrzebie rozważenia tego, w jakim stopniu teologia moralna służy jako przewodnik dla chrześcijańskiego życia i służby ${ }^{47}$. Szerokie doświadczenie duszpasterskie, płynące $z$ licznych prac podejmowanych poza działalnością naukową, jak odczyty, rekolekcje, rozmowy, publikacje w „Famiglia Cristiana”, domy modlitwy, stanowiło inspirację do nowego spojrzenia na ludzką moralność celem usunięcia przepaści pomiędzy życiem a nauczaniem.

Jako duszpasterz i teolog Häring poszukiwał dla chrześcijan dróg do odkrywania sensu zmieniania świata, w którym religijny i polityczny autorytaryzm popycha ludzi do fałszywego pojmowania siebie, Boga i wspólnoty. Tematy jego teologii moralnej, jak wolność, odpowiedzialność i egzystencjalny wybór, tworzą szczególnie teologiczną i praktyczną wizję chrześcijańskiego życia. W odpowiedzialności i w dialogu, a nie w moralnym obowiązku, Häring widzi sposób osiągnięcia pełnego naśladowania życia Chrystusa, które pobudza i podtrzymuje miłość człowieka do Boga. To nie jest przykazanie czy obowiązek, który zmusza wierzącego i prowadzi do zesztywnienia kultycznego i moralnego prawa, lecz naśladowanie Chrystusa osiągane jest przez kontakt wspólnoty z chrześcijańskimi znakami i symbolami, słuchanie i głoszenie słowa oraz udział w misteriach wiary ${ }^{48}$.

\subsection{Antropologiczna orientacja teologii moralnej}

Poświęcając uwagę człowiekowi, podmiotowi moralności, Häring konsekwentnie tworzy antropologię dla swojej teologii

\footnotetext{
47 Por. tamże, s. 20.

48 Por. tamże, s. 31.
} 
moralnej. Stanowi ona istotny rys jego myśli teologicznomoralnej. Nie jest to antropologia filozoficzna, lecz biblijna, wynikająca ze spotkania z konkretnym, wierzącym w Boga, naśladującym Chrystusa i otwartym na działanie Ducha Świętego człowiekiem. Przedstawiony w Biblii człowiek jest wzorem dla ludzi wszystkich czasów. Jest on stworzony z miłości przez Boga, upadający, grzeszny, wezwany do nawrócenia, odkupiony przez Jezusa Chrystusa i wezwany do naśladowania Go. Biblijny, a właściwie każdy człowiek żyje w konkretnym środowisku, czasie, które stawiają go w niepowtarzalnej relacji do Boga i bliźniego. Odejście od biblijnego obrazu człowieka prowadzi zdaniem Häringa nie tylko do oderwania się od rzeczywistości, lecz także do zafałszowania prawdy o nim. Antropologia biblijna ${ }^{49}$ ukazuje bowiem człowieka w świetle wezwania go przez Boga i jego odpowiedzi na to wezwanie.

Oprócz antropologii biblijnej Häring spogląda również na człowieka przez pryzmat personalizmu, egzystencjalizmu i fenomenologii ${ }^{50}$, a zwłaszcza myśli M. Schelera, M. Bubera, E. Lévinasa. Te nurty filozoficzne pomagają mu nie tylko w lepszym rozumieniu takich zagadnień jak osoba ${ }^{51}$, jej dialogiczny charakter i ukierunkowanie na Boga i drugiego człowieka (zwłaszcza Mit-sein - współ-bycie), wspólnota osób, wybór wartości, władze

49 Por. A. Karaś, Antropologia biblijna $w$ teologii moralnej w ujęciu Bernarda Häringa, „Studia Redemptorystowskie” 8 (2010), s. 139-161.

50 Por. tenże, Człowiek u podstaw odnowy teologii moralnej w ujęciu Bernarda Häringa, Kraków 2009, s. 125-160.

51 Już w pracy doktorskiej Häring analizuje myśl Schelera i przyjmuje jego dynamiczną koncepcję osoby, która m.in. polega na tym, że jej istotę stanowi miłość. Por. B. Häring, Nauka Chrystusa. Teologia moralna, t. IV: Świętość a dobro. Wzajemny stosunek religii i moralności, Poznań 1963, s. 154. 
duszy (rozumu, a zwłaszcza wolność), uczucia, ludzka natura ${ }^{52}$ $\mathrm{i}$ inne, ale również w tworzeniu własnego personalizmu ${ }^{53}$. Staraniom Häringa, by lepiej poznać człowieka, nie przyświeca jednak tworzenie antropologii dla niej samej, lecz dla odnowy teologii moralnej. W związku z tym ważnym dla niego pytaniem jest: Jakiego chce się mieć człowieka, wspólnotę? Kim

52 Häring wyraził swoje poglądy na temat ludzkiej natury zasadniczo w książce $W$ służbie człowieka. Teologia moralna a etyczne problemy medycyny, tłum. M. Oziembłowski, Warszawa 1975. Jego krytyka klasycznego ujęcia ludzkiej natury budzi wiele zastrzeżeń, a jego własne w wielu aspektach jest nie do przyjęcia, ponieważ zapodział w niej to, co stanowi jej istotę. Häring przypisuje tradycji arystotelesowsko-tomistycznej pomijanie prawa rozwoju człowieka. Sama teoria aktu i możności, która jest w tej tradycji fundamentalna, wyraża rozwój i doskonalenie się każdego bytu, w tym ludzkiego. Rozwój człowieka jednak dokonuje się przy udziale rozumu i wolności. Wybory człowieka i dążenie do prawdziwego dobra przynoszą rozwój jego osobie, natomiast złe wybory prowadzą do degradacji. Wydaje się, że Häring zagubił ten istotny sposób ludzkiego stawania się, który gwarantuje człowiekowi jego natura. Opowiadając się za dynamicznym ujęciem natury ludzkiej, podkreśla on $\mathrm{z}$ jednej strony doskonalenie się człowieka, lecz z drugiej strony pomija trwały i niezmienny wzorzec, w oparciu o który człowiek się doskonali, czyli rozumny i wolny wybór dobra przez jego cielesno-duchową naturę. Właśnie natura jest tym elementem każdego bytu, który gwarantuje i wyznacza jego ściśle określone stawanie się. W przypadku bytu ludzkiego natura zapewnia człowiekowi rozumne i wolne stawanie się, czyli doskonalenie się nie w dowolny, lecz ściśle określony sposób. Stanowi ona niezmienny wzorzec aktualizowania się bytu ludzkiego. Człowiek otrzymał od Boga zadanie stawania się w pełni sobą w oparciu nie tylko o zewnętrzne w stosunku do niego wzorce, jakimi są Boże przykazania, ale również w oparciu o immanentny, własny, wewnętrzny i osobowy wzorzec, jakim jest jego natura. Taki jest istotny sens zagadnienia natury ludzkiej, która stała się fundamentem moralnego nauczania Kościoła. Por. A. Karaś, Natura ludzka w ujęciu św. Tomasza z Akwinu i Bernarda Häringa, w: Pytając o prawdę rzeczywistości. Księga jubileuszowa z okazji 70. rocznicy urodzin Prof. dr. hab. Stanisława Bafii CSsR, red. M. Pawliszyn, Tuchów 2015, s. 61-83.

53 Por. A. Karaś, Człowiek u podstaw odnowy..., dz. cyt., s. 161-186. 
jest człowiek według zamysłu Boga? Odpowiedź na nie daje też odpowiedź na pytanie o rolę, zadanie i kierunek rozwoju teologii moralnej ${ }^{54}$. Jeżeli bowiem chce się mieć człowieka posłusznego prawu, to teologia moralna będzie się skupiać na tworzeniu tego prawa i norm. Jeżeli natomiast chce się mieć człowieka dojrzałego, powołanego przez Boga do wspólnoty z Nim i z bliźnim, to dla teologii moralnej ważne będą takie zagadnienia, jak sumienie osoby, jej wolność, odpowiedzialność i religijność.

\section{Wiodące tematy teologii moralnej}

Ten punkt stanowi dopełnienie poprzedniego. Wskazane wyżej kierunki odnowy teologii moralnej uzupełnione zostaną krótką charakterystyką ważnych dla Häringa tematów, którym poświęca w swoich pismach wiele uwagi. Pierwszy i drugi punkt, dopełniając się wzajemnie, przedstawiają charakterystyczne rysy jego teologii moralnej.

\subsection{Sumienie podstawą moralnego działania człowieka}

Do wiodących tematów teologii moralnej Häringa należy bez wątpienia zagadnienie sumienia. Istnieje wiele przesłanek, by uważać, że całe novum spojrzenia redemptorysty na człowieka i moralność wyraża się w jego koncepcji sumienia. Liczne książki i artykuły poświęcone temu zagadnieniu, jak również różnorodność jego ujęć, do których należą historia nauki o sumieniu, jego fenomenologiczne i biblijne wyodrębnienie, istota sumienia,

54 Por. B. Häring, Zeitgemässe und Unzeitgemässe Tugenden. Vortrag bei einer Tagung der Katholischen Akademie (Akademie-Publikationen, 68), Augsburg 1984, s. 23. 
formacja, wzajemność sumień, stosunek sumienia do władzy, jego rola w moralnym działaniu i inne, potwierdzają doniosłe znaczenie sumienia w moralnoteologicznej myśli Häringa. Wyróżnia on w sumieniu dwa wymiary: wymiar uzdolnienia i wymiar osądu, zwane inaczej trwałym uzdolnieniem oraz aktualnym osądem ${ }^{55}$.

Sumienie jako uzdolnienie jest „iskrą duszy”. Dusza jako podstawa jedności rozumu i woli stanowi o podobieństwie człowieka do Boga. Na tej antropologiczno-teologicznej podstawie opiera Häring moralność człowieka, która przejawia się w aktach sumienia jako uzdolnienia (synteresis) i jako konkretnego osądu (conscientia). Conscientia ogranicza się do pojedynczego aktu sumienia w odniesieniu do tego, co jest właściwe „tu i teraz”. Synteresis oznacza trwałą zdolność sumienia, wewnętrzne dążenie do prawdy w czynie. Dzięki owej habitualnej zdolności, czyli na podstawie swojej wewnętrznej natury, sumienie jest przyporządkowane prawdzie oraz wzywa człowieka do poznawania, niestrudzonego poszukiwania prawdy i wydawania właściwych sądów o dobru. „Iskra duszy”, która wyraża podobieństwo człowieka do Boga, sprawia, że jest on odpowiedzialny przed sobą samym i swoim Stwórcą za dążenie do prawdy i spełnianie dobra. $\mathrm{Na}$ tej podstawie sumienie pozwala się kierować Bogu za pomocą cnoty roztropności w unikaniu zła i dążeniu do dobra. Obejmuje ono nie tylko duszę, która chce być czymś jednym w sobie poprzez tworzenie jedności ze światem prawdy i dobra poprzez jedność rozumu i woli, lecz także istotne pokrewieństwo rozumu z prawdą o dobru oraz poznanie dobra i prawdy. Poznane dobro nie pociągałoby woli, gdyby nie była ona stworzona dla dobra,

55 Por. A. Karaś, Sumienie jako uzdolnienie i osąd w ujęciu Bernarda Häringa, „Analecta Cracoviensia” 42 (2010), s. 239-253. 
gdyby poznana wartość i natura woli nie wołały tą samą mową miłości. Poznający rozum nie tylko jest spokrewniony z prawdą, ale przez wrodzoną pramiłość dąży do dobra z pomocą woli. Podobnie wola jest nie tylko w jakiś sposób stworzona dla miłości, lecz przez zjednoczenie $\mathrm{z}$ rozumem w tej samej głębi duszy dąży do prawdziwego dobra.

Häring łączy indywidualne sumienie nie tylko z godnością osoby i prawdą, lecz także ze wspólnotą osób. Wspólnotę tę wyraża wzajemność sumień, która stanowi ponadto cenny wkład w stosunki między osobami, między sprawującymi władzę i podwładnymi oraz między hierarchią Kościoła a wiernymi. Häring zauważa, że tylko na drodze wzajemności sumień wzrasta autorytet władzy Kościoła. W ten sposób łączy w koncepcji sumienia subiektywność z obiektywnością. Ponadto analizy sumienia, jakich dokonuje Häring, stanowią cenne źródło na temat jego antropologicznych poglądów. Odnajduje się w nich rozwinięcie tomistycznego ujęcia, które ujmuje duszę ludzką jako substancję, źródło jedności władz i ich podłoże. Analizy te ukazują zatem moralność człowieka na tle jego natury, ontycznej struktury, a ostatecznie na tle religijności, a więc związku z Bogiem, na którego obraz i podobieństwo został stworzony.

\subsection{Chrześcijańskie działanie}

Do wiodących tematów teologii moralnej Häringa należy zaliczyć również chrześcijańskie działanie. Jest ono zorientowane w głównej mierze na poszanowanie drugiej osoby lub na odsłanianie tego, co wieczne, czyli Agape ${ }^{56}$. Działanie, które zmierza

56 Por. R. Tremblay, Was ist christliche Moral? Versuch einer Definition auf dem Hintergrund der Fußwaschung von Joh 13,1-20, w: In Christus zum 
do określonego celu, jest zdaniem Häringa rozwinięciem tego, co ludzkie (Humanitas). Człowieka należy wciąż na nowo pojmować w perspektywie tego, jaki on być powinien oraz jaki, w swojej wolności i mocą zbawczo-wyzwalającego czynu Boga w Chrystusie, być moż $\mathrm{e}^{57}$.

Chrześcijańskie działanie w myśli Häringa opiera się na ludzkiej wolności, która została stworzona przez Boga i staje się dla siebie samej odkupioną odpowiedzialnością. Ten fundament pozwala przejść od moralności nałożonej (Applikationsmoral) do etyki uzasadnienia (Begründungsethik). Etyka ta pod względem teologicznym traktuje poważnie moralność odpowiedzialności człowieka i uzasadnienie każdego działania jednostki ${ }^{58}$. Tym, co pozwala uzasadnić jednostce jej działania, jest wartość, którą urzeczywistnia dzięki wolności. Człowiek wolny doświadcza tego, że coś jest wartością, i kieruje się nią. Na gruncie więzi pomiędzy wolnością i doświadczeniem wartości moralności nigdy nie należy rozumieć jako ślepego imperatywu „przymusu”, lecz jako spotkanie wartości, które zwrócone jest na pojedynczą osobę i domaga się odpowiedzi. Odpowiedź tę wspomaga zachęta, by wykonać dany czyn, jeżeli chce się osiągnąć pełnię swojej osobowości.

R. Gallagher w ujęciu moralnego działania Häringa dostrzega istotną rolę religii i moralności. Zauważa, że religijność wyraża się poprzez dialog w wewnętrznej istocie osoby, w sumieniu, gdzie dynamika miłości jest doświadczana w pełni i najgłębiej. $\mathrm{W}$ tym

Leben befreit. Für Bernhard Häring, red. J. Römelt, B. Hidber, FreiburgBasel-Vien1992, s. 81.

57 Por. G.W. Hunold, „Moraltheologie im Umbruch”. Feststellungen zu den geschichtlichen Verwerfungen einer theologischen Disziplin, w: tamże, s. 57.

58 Por. tamże, s. 55-56. 
dialogu objawia się właściwa osobowość człowieka. Chrystus doświadczany jest nie tylko jako dar. Jest On także fundamentem, który umożliwia osobie prawdziwą, szczerą odpowiedź. To wyjaśnia, dlaczego uczestnictwo w boskim życiu, wspólnota z Chrystusem i dialog z Nim stają się fundamentem moralnej odpowiedzi osoby, czyli jej działania ${ }^{59}$. Na początku lat pięćdziesiątych XX wieku podręcznik do teologii moralnej rozumiano jako rozprawę naukową, w której ludzkie czyny omawiano w taki sposób, by odzwierciedlały podporządkowanie człowieka Bogu, celowi ostatecznemu (finis ultimus). Stanowiły one przedmiot materialny teologii moralnej, natomiast elementem formalnym było określone podporządkowanie ich Bogu jako ostatecznemu celowi ${ }^{60}$.

Istotę moralnego czynu charakteryzują nie tylko normy, lecz przede wszystkim Jezus Chrystus, który oznacza nowe bycie chrześcijanina. Takie ujęcie dowartościowuje rolę wiary w Chrystusa, przynależność chrześcijanina do Niego, a przede wszystkim przyczynia się do odpowiedzialności i dojrzewania w wierze. U podstaw więzi z Chrystusem leży przymierze Boga z Jego ludem. Dynamiczna obecność Chrystusa przejawia się w udzielanej każdemu człowiekowi łasce oraz wzroście Bożego życia w człowieku. Łaska nie wyczerpuje religijnego pierwiastka w moralnym działaniu ludzkim. Häring uzupełnia go cnotami teologicznymi.

Do istoty moralnego aktu należy także wolność, która będąc darem Boga, jest możnością czynienia dobra. Wszystkie akty i jakość pojedynczego aktu zależą od opcji fundamentalnej, w której Häring akcentuje cel ostateczny, a więc przylgnięcie

59 Por. R. Gallagher, „Das Gesetz Christi”..., dz. cyt., s. 20-21.

60 Por. tamże, s. 12. 
do Chrystusa. Oparcie opcji fundamentalnej na wezwaniu Boga i odpowiedzi człowieka na to wezwanie ukazuje także jej związek z cnotami teologicznymi. Opcja fundamentalna jako pryncypium moralnej dobroci i sprawczości daje człowiekowi jedność, całość, siłę wzrostu oraz prawdziwość.

Istotnym elementem pojedynczego aktu moralnego i całego działania człowieka jest moralne przeżycie wartości, które pojawia się w wyniku spotkania podmiotu z wartością i domaga się od niego odpowiedzi. Niekiedy przeżycie wartości zostaje ubogacone przeżyciem religijnym. Wówczas wartość zostaje podniesiona do rangi świętości, a odpowiedź na nią dokonuje się w aktach religijnych. Bezwzględny charakter przeżywanej wartości, czyli dobra, rodzi w podmiocie powinność, która nie jest nakazem, lecz wymogiem uznania jej. Powinność ta z kolei odwołuje się do wolności podmiotu, nie naruszając jej, oraz domaga się od niego odpowiedzi, która wyraża się w wyborze wartości. Häring zauważa, że u podstaw moralnej decyzji leży nie norma moralna ani sumienie, lecz miłość do Boga.

Do struktury moralnego przeżycia wartości w działaniu Häring zalicza także przeżycie sumienia. Przemawia w nim nie tylko wartość od zewnątrz i przerażona o swą jedność dusza, lecz uwydatnia się także obok rozumu natura wolnej woli. Wola stosownie do swej natury nie może dążyć do bezwartości, lecz jedynie do wartości, czyli dobra.

Zwrócenie uwagi na podmiotowy wymiar moralnego działania i złączenie go z przedmiotowym pozostaje bez wątpienia zasługą Häringa. Każdy człowiek w konkretnej sytuacji winien nie tylko postępować według norm moralnych, lecz także rozpoznawać znaki czasu i dążyć do prawdy, przestrzegając zasady 
wzajemności sumień. Ta droga w życiu moralnym prowadzi do kształtowania dojrzałych i odpowiedzialnych chrześcijan. Wychodząc od dynamicznej, historycznej, rozwijającej się w czasie, historii i w postępie cywilizacji koncepcji człowieka, Häring domaga się uwzględnienia nowych wyzwań i nowego spojrzenia na moralność. Nie oznacza to zmiany celu, jakim jest świętość i doskonałość, do czego człowiek jest powołany. Nie oznacza to też zmiany norm, które Chrystus zawarł w Kazaniu na górze, ani odejścia od wiary i Chrystusa, lecz jest to odpowiedź Panu historii dawana tu i teraz.

\subsection{Historyczność prawa naturalnego}

Zagadnieniem, które Häring często podejmował, było prawo naturalne. Ponieważ znalazło się ono na liście zarzutów w procesie wszczętym przeciw niemu przez Kongregację Nauki Wiary, o czym sam wspomina w swojej autobiograficznej książce ${ }^{61}$, dlatego kwestia ta domaga się szerszego i całościowego opracowania, co w ramach niniejszego tekstu jest niemożliwe ${ }^{62}$. Gruntowne przebadanie tego tematu pozwoliłoby lepiej poznać ten wątek myśli Häringa. Analizując jego wypowiedzi zawarte w różnych i bardziej znaczących publikacjach, nie zauważa się naruszenia nauczania Kościoła w tej materii.

61 Por. B. Häring Meine Erfahrung mit der Kirche. Einleitung und Fragen von Gianni Licheri, Freiburg-Basel-Vien 1989, s. 134. Zbadanie tego wątku jest o tyle trudne, że znana jest jedynie odpowiedź Häringa na ten zarzut, natomiast autor nie podaje jego treści sformułowanej przez Kongregację Nauki Wiary.

62 Więcej na temat prawa naturalnego w ujęciu Häringa zob. A. Karaś, Człowiek u podstaw odnowy..., dz. cyt., s. 292-313. 
Do nowego spojrzenia na prawo naturalne skłania Häringa historyczny wymiar ludzkiej natury. Odróżnia on niezmienność prawa naturalnego od zmiennego zastosowania go w zmieniających się warunkach. Historyczność prawa naturalnego jest trwałą i istotną płaszczyzną człowieka oraz wpisanego w jego naturę moralnego prawa. Prawo moralne odzwierciedla ludzką egzystencję w określonych uwarunkowaniach historycznych oraz opiera się na konfrontacji doświadczenia pojedynczych osób i całej wspólnoty. Takie ujęcie jest konsekwencją dynamicznego podejścia do bytu ludzkiego z całkowitą świadomością jego historycznego kontekstu. Brak historyczności w dotychczasowym podejściu do prawa naturalnego i ludzkiej natury związany był $\mathrm{z}$ ich racjonalistycznym i statycznym pojmowaniem. Häring łączy historyczne ujęcie człowieka $\mathrm{z}$ obecnym etapem historii zbawienia oraz poznania objawiającego się Boga. Z zasady niezmienności prawa naturalnego i zmiennego zastosowania go w zmieniających się warunkach wyprowadza podstawową zasadę podmiotowego prawa, że człowiek musi historycznie słusznie działać, lecz nie można statycznie raz na zawsze ustalić, co jest historycznie słuszne. Dopiero poznanie zawsze obowiązujących podstawowych zasad podmiotowego prawa naturalnego i historycznej sytuacji umożliwia osądzenie, co jest historycznie, a tym samym naturalnie słuszne.

\subsection{Grzech z perspektywy nawrócenia}

Kolejnym i ważnym tematem zarówno dla teologii moralnej, jak i moralności jest grzech. Pośród wielu aspektów teologicznomoralnej refleksji nad grzechem, które podjął Häring, na uwa- 
gę zasługuje kwestia nawrócenia ${ }^{63}$. Wezwanie do niego stanowi zasadniczą treść biblijnego przesłania skierowanego do człowieka, który odszedł od Boga poprzez grzechy. Perspektywa ta jest dla Häringa wyjątkowo ważna, a jednocześnie podkreśla on konieczność nie tylko biblijnego pogłębienia teologicznomoralnej refleksji nad grzechem. Głębszą rację spojrzenia na grzech z perspektywy nawrócenia wydaje się stanowić wyraźny sprzeciw niemieckiego moralisty wobec takiej praktyki, w której teologia moralna traci z pola widzenia nawrócenie człowieka, a skupia się na samym grzechu, czego przykładem może być ustalanie granicy pomiędzy grzechem śmiertelnym a lekkim bez uwzględniania podmiotu działania lub podawanie katalogów grzechów. Zadaniem teologii moralnej jest bowiem również wyznaczanie właściwych kierunków dla przeżywania i sprawowania sakramentu pokuty i pojednania, który powinien być przede wszystkim sakramentem nawrócenia. Całe novum ujęcia grzechu z perspektywy nawrócenia w myśli Häringa dobrze oddaje przykład człowieka ze skrupułami. Uwaga skrupulata koncentruje się na grzechu lub na tym, co w rzeczywistości grzechem nie jest, a pomija prawdziwe dary Boga, Jego miłość, odkupienie i wyzwolenie z grzechu dokonane w Chrystusie, wezwanie do radosnego i odpowiedzial-

63 Häring podkreśla aspekt nawrócenia w wielu swoich publikacjach. Najobszerniej omawia go w Frei in Christus. Moraltheologie für die Praxis..., t. I, dz. cyt., s. 367-438 oraz w Grzech w wieku sekularyzacji, tłum. H. Bednarek, Warszawa 1976. Równie ważnym i istotnym aspektem refleksji nad grzechem, któremu poświęca uwagę, jest aspekt soteriologiczny, czyli zbawienia lub odkupienia. Podkreśla on dzieło zbawcze Boga, dokonane w Jezusie Chrystusie, czyli pełne miłości działanie Boga, by wybawić człowieka z grzechu. Por. tenże, Frei in Christus. Moraltheologie für die Praxis..., t. I, dz. cyt., s. 371 n.; tenże, Moraltheologie für das dritte Jahrtausend, Graz-Wien-Köln 1999, s. 59-87. 
nego kroczenia za Nim, które polega na świadomym wybieraniu i pełnieniu dobra, a odrzucaniu zła. Wiele podobieństw do tego podejścia zdaje się zawierać nauka o grzechu w teorii i praktyce. Poszukiwanie grzechu i dostrzeganie go u siebie lub innych może tak zaabsorbować, że zatraci się najważniejsze orędzie Biblii, czyli wezwanie Boga do nawrócenia i przemiany życia.

Teologia moralna nie może zapominać o tym, w jakim celu naucza o grzechu. Nie jest nim samozadowolenie, że tak precyzyjnie i z uwzględnieniem wszelkich dystynkcji ujęła grzech i potrafi doskonale odróżnić lekki od śmiertelnego, wskazać, kiedy mamy do czynienia z pierwszym, a kiedy z drugim. Teologia moralna traktuje o grzechu jedynie po to, by człowiek mógł odnaleźć drogę do Boga, by wszedł na nią i nią kroczył. Oznacza to, że musi ukazać człowiekowi rzeczywistość grzechu w taki sposób, by zrozumiał, jak bardzo on go niszczy i oddala od Boga, oraz że Bóg w Jezusie Chrystusie pokonał wszelki grzech i jedynie w Chrystusie i z Nim człowiek może pokonywać grzech w swoim życiu.

\subsection{Zasada „złotego środka”}

pomiędzy subiektywnością a obiektywnością

Häring dostrzegł źródło kryzysu teologii moralnej w sporze pomiędzy subiektywnością a obiektywnością. Ujawnił się on w czasach nowożytnych, a po Soborze Watykańskim II nabrał szczególnej wyrazistości. Jednakże nie jest to jedynie spór pomiędzy Magisterium Kościoła a niektórymi teologami, lecz ma on najpierw miejsce w sumieniu każdego człowieka, który pyta o źródło moralności czynów oraz o uzasadnienie norm. 
Propozycja Häringa, by rozwiązać kryzys w teologii moralnej, oparta jest na jego osobistych przemyśleniach oraz na słuchaniu ludzi, z którymi się spotykał, rozmawiał, pracował, żył i praktykował wiarę. Do tych bliskich mu osób zaliczali się nie tylko wierni świeccy, ale również wysoko postawieni w hierarchii Kościoła duchowni. Dla Häringa ważne jest wspólne dążenie, dorastanie i dojrzewanie oraz droga do prawdy. Wspólne dążenie możliwe jest tylko we wzajemności sumień, wymianie doświadczeń, ponieważ nikt nie ma monopolu na prawdę. Nawet szczególna asystencja Ducha Świętego nie zwalnia człowieka z respektowania sumienia innych ludzi oraz dzielenia się nawzajem doświadczeniem. W ten sposób Häring ukazał nie tylko fundament życia wspólnoty, ale również moralną siłę uczestnictwa i współuczestnictwa wszystkich jej podmiotów.

Moralność chrześcijańska w ujęciu Häringa sprowadza się do znalezienia złotego środka pomiędzy obiektywnością a subiektywnością. Pedagogika Boża zdaje się mieć go w miłości i przebaczeniu, które znajdują się pomiędzy przykazaniem a wolnością. Zasada „złotego środka” stworzona przez Häringa polega na tym, że przyznaje on człowiekowi, podmiotowi poznającemu, autonomię sumienia oraz wolność i jednocześnie nie zwalnia go z obowiązku dążenia do prawdy, nawracania się, przemiany i refleksji nad osądami sumienia i własnymi czynami. Głos Häringa staje się zachętą do ponownego przemyślenia relacji pomiędzy obiektywnością i subiektywnością zarówno w praktyce życia wiernych, jak i w nauczaniu Kościoła. 


\section{Przyczyny różnic z oficjalną nauką Kościoła}

Wydaje się, że drugorzędną przyczyną napięć Häringa z Magisterium oraz krytyki ze strony niektórych teologów były jego poglądy, które rodziły wątpliwości co do ich zgodności z nauką Kościoła. Dotyczy to zwłaszcza takich zagadnień, jak ludzka natura i związana z nią zgoda na antykoncepcję, prawo naturalne, uzasadnianie norm moralnych ${ }^{64}$. Skoro jednak były one drugorzędną przyczyną różnic $\mathrm{z}$ oficjalną nauką Kościoła, to co w takim razie stanowiło pierwszorzędną? Moim zdaniem, leży ona w braku stosowania terminologii filozofii klasycznej ${ }^{65}$, na której gruncie zostało wypracowanych wiele pojęć pozwalających wyrazić naukę Kościoła w sferze filozofii, teologii, a więc również teologii moralnej. Häring wiele razy wyrażał swój zachwyt wobec współczesnych mu nurtów myślowych, jak personalizm, egzystencjalizm, fenomenologia, chociaż nie był wobec nich bezkrytyczny. Jedno natomiast wydaje się łączyć te nurty z postawą redemptorysty: wspólna niechęć do języka filozofii klasycznej. Jednym z postulatów odnowy teologii moralnej, na który Häring kładł nacisk, było uwolnienie tej dyscypliny od skostniałej terminologii

64 Dla przykładu, Häring uważa, że biologiczne prawa, które rządzą jego organizmem, nie mogą stanowić normy postępowania. Por. tenże, Frei in Christus. Moraltheologie für die Praxis..., t. I, dz. cyt., s. 311. Więcej na temat uzasadniania norm w myśli Häringa zob. A. Karaś, Człowiek u podstaw odnowy..., dz. cyt., s. 313 n.

65 Häring uważa, że Magisterium Kościoła w spojrzeniu na prawo naturalne nie powinno uwzględniać filozofii czy też krótkotrwałego doświadczenia, lecz kierować się porządkiem zbawienia, a więc myśleniem i działaniem człowieka otwartego na wiarę w historię zbawienia i w ponadhistoryczną rzeczywistość. Por. tenże, Unglaube und Naturrecht, w: Theologie im Wandel. Festschrift zum 150 Jährigen Bestehen der katholisch-theologischen Fakultät an der Universität Tübingen 1817-1967, cz. I, München-Freiburg 1967, s. 216-226. 
scholastycznej ${ }^{66}$. Czy za tym postulatem stała osobista niechęć do filozofii klasycznej? Trudno na to pytanie odpowiedzieć. Aparatura pojęciowa zaczerpnięta $z$ egzystencjalizmu, personalizmu czy też z fenomenologii nie pozwala oddać rzeczywistości dotyczących ontologii, a zwłaszcza ontologii bytu ludzkiego, prawa naturalnego, ludzkiej natury, substancjalności. Stąd wyjaśnianie bytu ludzkiego, jego rozwoju i działania w świetle ostatecznych zasad (teoria aktu i możności, złożenie materii i formy, substancja, istota, natura itd.), co stanowi przedmiot filozofii i antropologii klasycznej, za pomocą innej terminologii musi budzić wątpliwości. Wyrażając istotne treści za pomocą współczesnych i bliższych mu pojęć języka niemieckiego, zagubił w myśleniu o człowieku to, co ważne i na czym po dziś dzień opiera się nauka Kościoła. Jego zwrot ku antropologii biblijnej i poszukiwanie jedynie w Piśmie Świętym pełnego zrozumienia człowieka oraz rezygnacja $\mathrm{z}$ aparatury pojęciowej filozofii klasycznej, która dla nauki Kościoła katolickiego jest równie ważna jak język biblijny, stały się mimowolną przyczyną trudności w akceptacji jego myśli. Filozofia klasyczna i oparta na niej antropologia pozwalają rozumieć ontologię bytu ludzkiego i całej rzeczywistości. Nowożytne nurty myślowe $\mathrm{z}$ racji innego punktu wyjścia, swych założeń i sposobu filozofowania wprawdzie dostarczają bogatszego opisu człowieka, lecz jest to opis „fenomenu” czy też „zjawiska” człowieka. Dążąc do pełnego wyjaśnienia ludzkiego bytu, do jego zrozumienia i ujęcia ostatecznych racji istnienia, działania i rozwoju, nie można pominąć antropologii opartej na filozofii klasycznej. Jeżeli się to czyni, natychmiast pojawia się ryzyko błędnego rozumienia istoty ludzkiej, jej moralnego działania i dążenia do pełni.

66 Por. F. Greniuk, Katolicka teologia moralna..., dz. cyt., s. 42. 


\section{Znaczenie myśli teologicznomoralnej Bernharda Häringa}

Wspomniane różnice pomiędzy myślą Häringa a oficjalną nauką Kościoła, które zwłaszcza w sferze rozumienia ludzkiej natury są nie do przyjęcia, z pewnością nie przysłaniają i nie mogą przysłonić ogromu jego pracy na polu odnowy teologii moralnej w drugiej połowie XX wieku. Wydaje się, że jego wkład na zawsze zmienił teologię moralną przedsoborową, w której się wychowywał i dorastał. Podejście do moralności oraz podejście do człowieka, dla którego uczynił moralność zrozumiałą i przystępną, sprawiły, że jego śladami poszło wielu współczesnych mu teologów moralistów, jak również wytyczył on szlaki dla refleksji teologicznomoralnej na wiele dziesiątków, a może i setek lat. Wymienione ważniejsze charakterystyczne rysy teologii moralnej w jego ujęciu, które zostały wskazane w punkcie pierwszym, wiodące tematy wzmiankowane $\mathrm{w}$ drugim oraz wiele innych zagadnień, jak bioetyka, wyścig zbrojeń, przemoc, pokój, małżeństwo i rodzina, potwierdzają słuszność obranego przez niego kierunku dla tej dyscypliny teologicznej i będą stanowiły inspirację dla moralistów w przyszłości. 